\title{
International Standardization of Common Names for Iberian Endemic Freshwater Fishes
} Pedro M. Leunda ${ }^{1, *}$, Benigno Elvira ${ }^{2}$, Filipe Ribeiro
Judite Alves
5,6

${ }^{1}$ GAVRN-Gestión Ambiental Viveros y Repoblaciones de Navarra S.A., C/ Padre Adoain 219 Bajo, 31015 Pamplona/Iruña, Navarra, España.

${ }^{2}$ Universidad Complutense de Madrid, Facultad de Biología, Departamento de Zoología y Antropología Física, 28040 Madrid, España.

${ }^{3}$ Virginia Institute of Marine Science, School of Marine Science, Department of Fisheries Science, Gloucester Point, 23062 Virginia, USA.

${ }^{4}$ Universidad de Navarra, Departamento de Zoología y Ecología, Apdo. Correos 177, 31008 Pamplona/Iruña, Navarra, España.

${ }^{5}$ Universidade de Lisboa, Faculdade de Ciências, Centro de Biologia Ambiental, Campo Grande, 1749-016 Lisboa, Portugal.

${ }^{6}$ Museu Nacional de História Natural, Universidade de Lisboa, Rua da Escola Politécnica 58, 1269-102 Lisboa, Portugal.

*Corresponding author: pedro.leunda@gavrn.com

Received: 8/10/08

Accepted: 22/5/09

\begin{abstract}
International Standardization of Common Names for Iberian Endemic Freshwater Fishes

Iberian endemic freshwater fishes do not have standardized common names in English, which is usually a cause of inconveniences for authors when publishing for an international audience. With the aim to tackle this problem, an updated list of Iberian endemic freshwater fish species is presented with a reasoned proposition of a standard international designation along with Spanish and/or Portuguese common names adopted in the National Red Data Books.
\end{abstract}

Key words: Standard designation, ichthyofauna, Spain, Portugal.

\section{RESUMEN}

Estandarización Internacional de los Nombres Comunes para los Peces Dulceacuícolas Endémicos de la Península Ibérica

Las especies de peces dulceacuícolas endémicas de la península Ibérica carecen de nombres comunes en inglés, lo cual frecuentemente causa inconvenientes a los autores en el momento de publicar para una audiencia internacional. Con el objetivo de llenar este vacío, se presenta una lista actualizada de las especies de peces dulceacuícolas endémicas de la península Ibérica con una propuesta razonada de designación internacional estandarizada junto con los nombres comunes en español y/o portugués adoptados en los Libros Rojos Nacionales.

Palabras clave: Designación estándar, ictiofauna, España, Portugal.

\section{RESUMO}

Padronização Internacional dos Nomes Comuns dos Peixes Dulciaquícolas Endémicos da Península Ibérica

Os peixes dulciaquícolas endémicos da Península Ibérica não possuem um nome comum devidamente padronizado em Inglês, o que causa problemas aos investigadores quando publicam em revistas com uma audiência internacional. O presente trabalho procurou resolver esta questão, incluindo uma lista actualizada das espécies piscícolas endémicas da Península Ibérica e uma proposta fundamentada de nomes comuns em Inglês, juntamente com as designações comuns em Espanhol elou Português adoptadas nos respectivos Livros Vermelhos Nacionais.

Palavras-chave: designação padrão, ictiofauna, Espanha, Portugal. 


\section{INTRODUCTION}

Endemic species of non-English speaking countries do not have standardized common names in English and Iberian fish species may be considered a good example (Froese \& Pauly, 2008; IUCN, 2008). The absence of common names in English for an international use is usually the cause of inconveniences for authors when publishing scientific, technical, legal or academic contributions. Specifically, during the manuscript preparation and review processes, editors and/or reviewers of some international journals require full names -i.e. common and scientific names with authority - whilst others prefer to use vernacular names in the title, introducing the fish species' scientific names in the abstract. In such cases, it is for the author consideration to attribute/create an international common designation, leading to a growing variety of vernacular names in English for Iberian fishes and other endemic ichthyofaunas in non-English speaking regions.

Some of the English common names for Iberian fishes have been used consistently enough that became almost standard. However, it is frequent to find in literature the same common name referring to different species, for example, "Iberian barbel" which could correspond to any of the nine endemic species presently recognized within the genus Barbus. Additionally, it is common to find the same species with different common names in English, due to direct translation of local languages vernacular names. This is utmost problematic in the Iberian Peninsula, where several languages (Portuguese, Spanish, Basque, Catalonian, and Galician) are officially recognized and many more local dialects are spoken. Such linguistic diversity inevitably resulted in several vernacular names for a single species but also to several species sharing the same name in different regions. To overcome such problems, sometimes editors and/or reviewers of international journals recommend using only the species scientific name along the manuscripts, resulting in tedious papers, regardless of the content, especially when several fish species names are mentioned repeatedly. As a rule, scientific names should be included and prioritized in the title -without author(s) and year- and given complete in their first appearance in the abstract and introduction sections.

Here, we present an updated list of Iberian endemic freshwater fish species with Spanish and/or Portuguese vernacular names adopted in the National Red Data Books (Doadrio, 2001, 2002; Rogado et al., 2005; but see also CollaresPereira et al., 2007; Ribeiro et al., 2007) along with a reasoned proposition of a standard international designation. Genera within a given family are presented in alphabetical order, as are species within a given genus.

Our standardization effort obeyed, whenever possible, to former common names, adopted by earlier authors and used in the literature, but some new names are now proposed if we considered earlier ones inaccurate, geographically biased or scientifically unsatisfactory. For example, names that include geographical areas or drainages are preferred against current administrative provinces, autonomous regions or countries, in order to link common name with accurate species distribution, avoiding inappropriate regional or local names. We also avoided common names with designations of genera that do not occur in Iberia (e.g., roach $=$ Rutilus). Moreover, in some Iberian endemic genera we recommend, with some exceptions (already traditionally well-established), the local language name as the most appropriate standard common name.

As far as we know, the only similar standardization effort in Europe was carried out for the British Isles fish fauna (Wheeler, 1992; Wheeler et al., 2004). However, the American Fisheries Society (AFS) publishes updated lists (e.g., Nelson et al., 2004) of common and scientific names for North American species. Based on this, the AFS also has developed a fish name spellchecker software as an aid to authors and editors of fisheries science papers. We encourage scientific associations or research groups from other regions to coordinate the agreement and completion of similar lists for their ichthyofauna.

The list we present here (see Table 1) should be considered a live document where additions, corrections, comments and suggestions are welcome. 


\section{STANDARD NAMES AND JUSTIFICATION}

\section{Family Cyprinidae}

1.1 Achondrostoma arcasii (Steindachner, 1866). Spanish: Bermejuela. Portuguese: Panjorca. Standard name: Bermejuela. The species was described as Leuciscus, and after transferred to the genera Rutilus first, and Chondrostoma later, thus receiving in the literature common names such as "(Iberian) red roach" or "bermejuela nase". Recently, based on the putative congruence between molecular and morphological characters, Robalo et al. (2007) proposed five new genera within Chondrosto$m a$ s.l., and the species was assigned to the new Iberian endemic genus Achondrostoma. However, the proposed generic changes still raise some concerns (see comments on Iberochondrostoma olisiponensis). Endemicity of the genus no longer supports name combinations previously used, which incorrectly evoke other genera. It presents a wider distribution range in Spain and therefore we recommend the standard designation of "Bermejuela" as also adopted by Kottelat \& Freyhof (2007).

1.2 Achondrostoma occidentale (Robalo, Almada, Sousa-Santos, Moreira \& Doadrio, 2005). Portuguese: Ruivaco do Oeste. Standard name: Western ruivaco. The natural distribution of the species is restricted to some coastal and central drainages in western Iberia. The Portuguese endemicity of this newly described species (Robalo et al., 2005a) recommends the use of the translation of its national vernacular name (Robalo et al., 2008).

1.3 Achondrostoma oligolepis (Robalo, Doadrio, Almada \& Kottelat, 2005). Portuguese: Ruivaco. Standard name: Ruivaco. The replacement name for Leuciscus macrolepidotus Steindachner, 1866 given by Robalo et al . (2005b) was Chondrostoma oligolepis. The Portuguese endemicity of this species and its wider natural distribution range (from Lima to Tornada drainages) when compared to $A$. occidentale suggests the adoption of its single vernacular name as appropriate.
1.4 Achondrostoma salmantinum Doadrio \& Elvira, 2007. Spanish: Sarda. Standard name: Sarda. This recently described species has a narrow distribution range encompassing the Huebra, Turones and Uces catchments within the Duero River basin in southwestern Spain. Such a regional range justifies the appropriateness of its local name as standard designation (Doadrio \& Elvira, 2007).

1.5 Anaecypris hispanica (Steindachner, 1866). Spanish: Jarabugo. Portuguese: Saramugo. Standard name: Jarabugo. The Iberian endemicity of the genus with this single species could recommend both Spanish and Portuguese vernacular names (Kottelat \& Freyhof, 2007), since it occurs in both countries along the Guadiana River basin (Collares-Pereira \& Cowx, 2001). However, Steindachner described the species in 1866 (as Phoxinellus hispanicus) based on specimens collected in a small Guadiana tributary in Spain. Because it was firstly recorded by the Spanish vernacular name, we recommend the standardization of this older designation - the first citation to the Portuguese Guadiana was indeed posterior (Collares-Pereira \& Almaça, 1979). Moreover, the Portuguese name may well be confused with the vernacular name of another quite distinct endemic species -the "Samaruc" (see Valencia hispanica).

1.6 Barbus bocagei Steindachner, 1865. Spanish: Barbo común. Portuguese: Barbo-comum. Standard name: Iberian barbel. Due to the still ongoing doubts about the generic status (Barbus, Luciobarbus), we maintain all Iberian barbels in the previous single genus Barbus until further studies are carried on, to avoid nomenclatural instability. Even though several endemic barbel species inhabit Iberia and thus have shared this name in the literature, this species has the broadest natural distribution range within Iberia, occurring in the Atlantic slope drainages from the Lima to the Sado River basins, including the two largest Iberian drainages Tagus and Douro.

1.7 Barbus comizo Steindachner, 1865. Spanish: Barbo comizo. Portuguese: Cumba. 


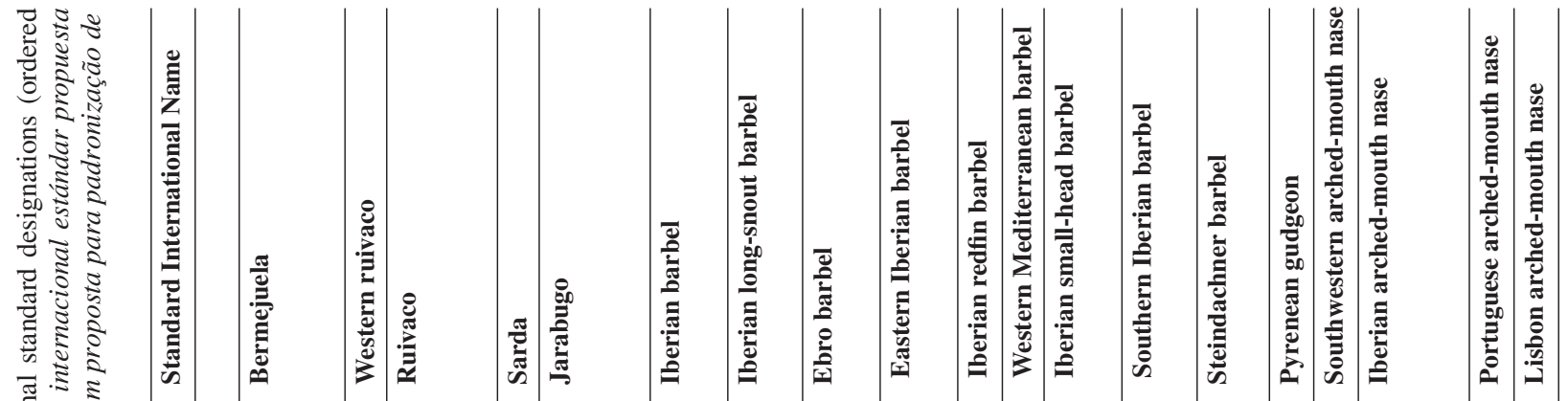
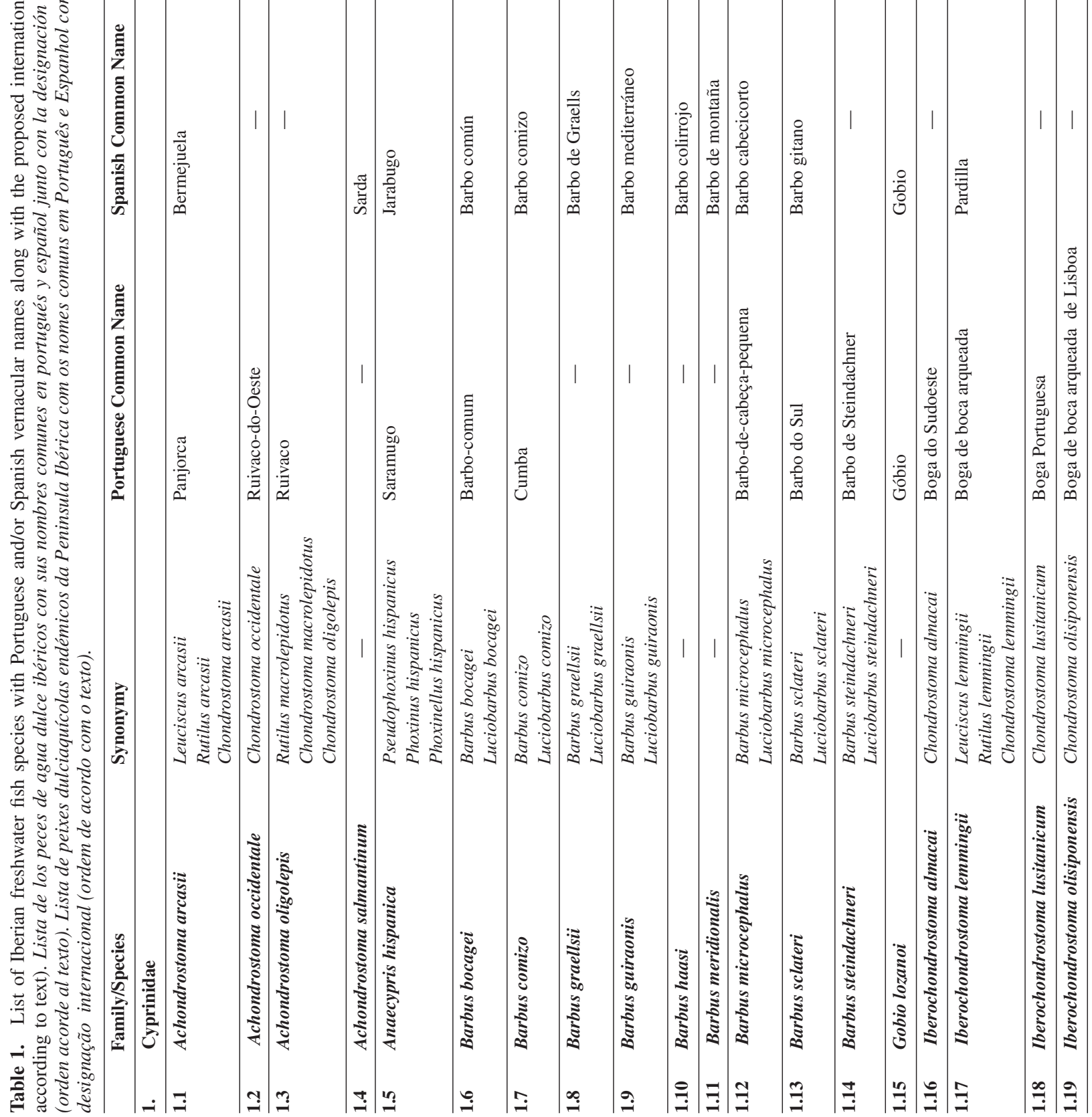

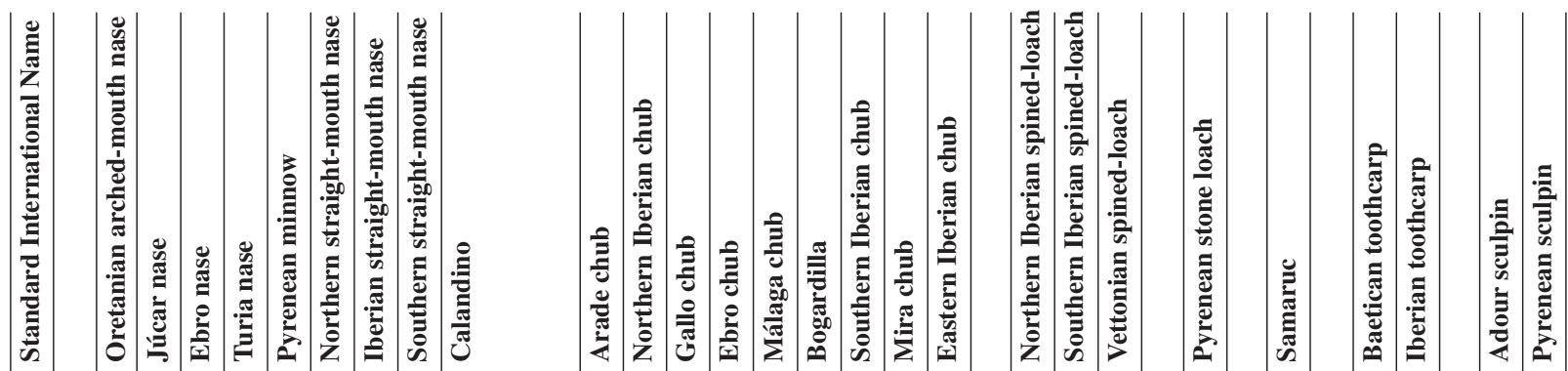

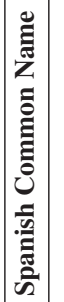
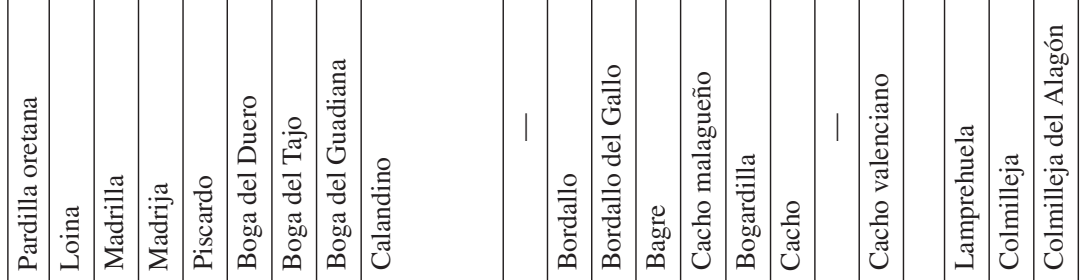

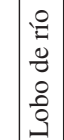

䔍

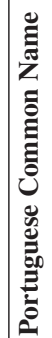
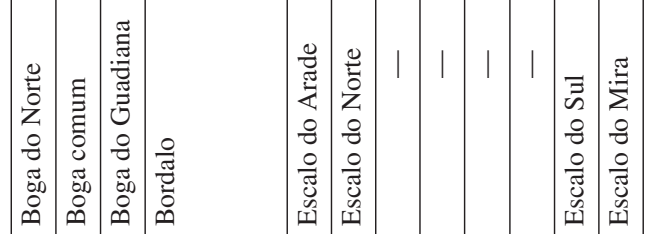

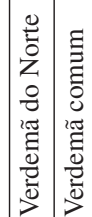
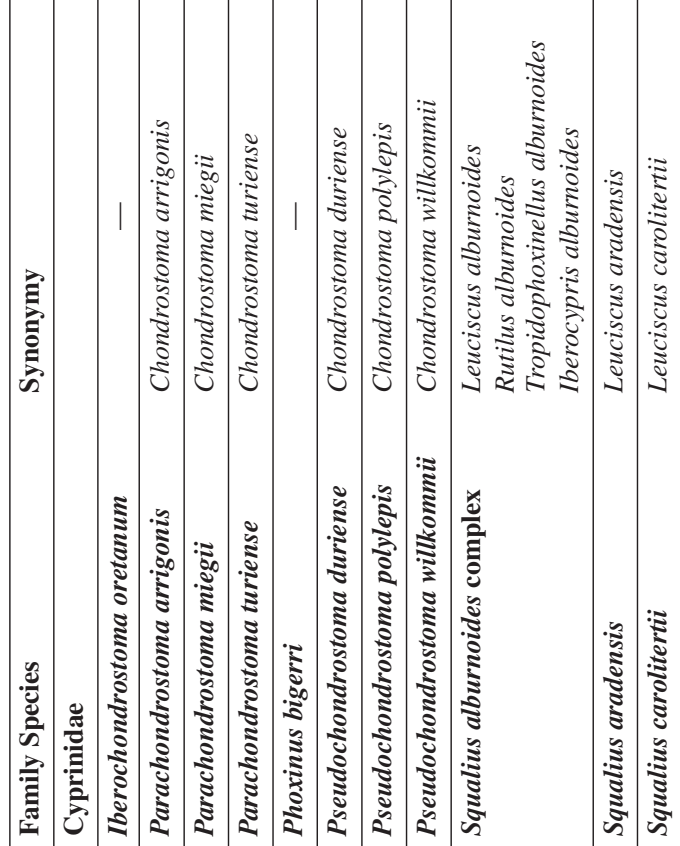

2

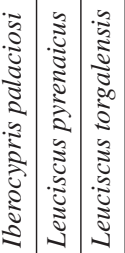

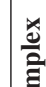

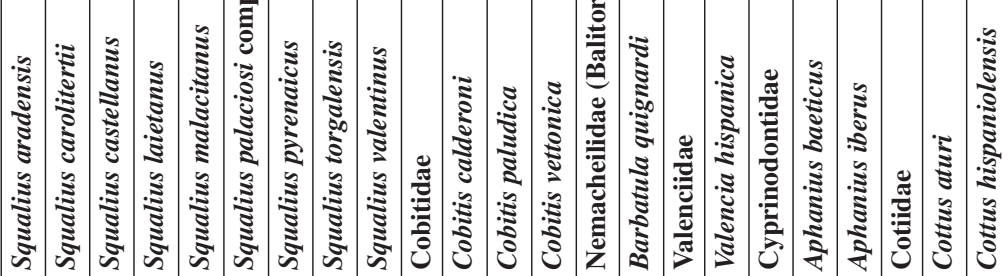

-

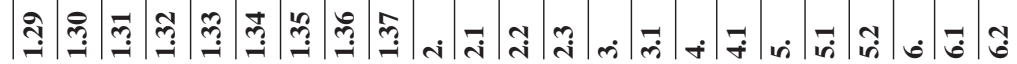


Standard name: Iberian long-snout barbel. This species is native to both Iberian countries inhabiting currently the Tagus and Guadiana drainages. Therefore, we recommend the use of this English common name, which was occasionally used in the scientific literature, and derives from the characteristic head shape result of the pronounced snout elongation in adult specimens (Doadrio \& Perdices, 1998), instead of a derived latin name "comizo barbel" (Kottelat \& Freyhof, 2007). See also earlier comments on the genus in B. bocagei.

1.8 Barbus graellsii Steindachner, 1866. Spanish: Barbo de Graells. Standard name: Ebro barbel. The species natural and current distribution range includes most of the Ebro River basin and some neighbouring small basins draining to the Mediterranean Sea and the Bay of Biscay. We found more accurate and appropriate the name "Ebro barbel" than others that have been used in the literature such as "common barbel", "Iberian barbel" (see earlier comments on $B$. bocagei), or "Graells barbel" (see comments on B. steindachneri). See also earlier comments on the genus in B. bocagei.

1.9 Barbus guiraonis Steindachner, 1866. Spanish: Barbo mediterráneo. Standard name: Eastern Iberian barbel. The species inhabits streams draining to Mediterranean Sea between Ebro (north) and Vinalopó (south) (but not included), in the eastern coast of Spain. This name is preferred over "Valencia barbel" (Kottelat \& Freyhof, 2007) because Valencia in only one of the provinces within the distribution area of the species. See also earlier comments on the genus in B. bocagei.

1.10 Barbus haasi Mertens, 1924. Spanish: Barbo colirrojo. Standard name: Iberian redfin barbel. The native and current distribution range includes most of the Ebro River basin and neighbouring small basins of the Mediterranean slope (Miranda et al., 2005). We propose "Iberian redfin barbel" as standard common name in English because the Spanish vernacular name also makes reference to the red pigmentation of the anal, caudal and pelvic fins during the spawning season. We discourage from using "Catalonian barbel" (Kottelat \& Freyhof, 2007) since Catalonia is only one of the nine autonomous regions sharing the Ebro River basin.

1.11 Barbus meridionalis Risso, 1827. Spanish: Barbo de montaña. Standard name: Western Mediterranean barbel. Its natural and present distribution range is limited to the rivers draining to Mediterranean Sea in northeastern Spain and southern France. There has been some consensus in the literature for the use of "Mediterranean barbel" (e.g., Kottelat \& Freyhof, 2007) but many other barbel species occur in the Mediterranean area, therefore we recommend a more precise geographic confinement.

1.12 Barbus microcephalus Almaça, 1967. Spanish: Barbo cabecicorto. Portuguese: Barbode-cabeça-pequena. Standard name: Iberian small-head barbel. The species is native of the Guadiana River basin. This name is preferred because the scientific designation as well as the Spanish and Portuguese common names make reference to the reduced size of its head when compared to other Iberian barbel species. See also earlier comments on the genus in B. bocagei.

1.13 Barbus sclateri Günther, 1868. Spanish: Barbo gitano. Portuguese: Barbo do Sul. Standard name: Southern Iberian barbel. The southern Iberian distribution range of the species, beyond the limits of the autonomous region of Andalusia, discourages the name "Andalusian barbel" used by Kottelat \& Freyhof (2007). We also advise against the English translation of its Spanish name, i.e. "Gipsy barbel", which has already been used in the literature, in order to avoid terms that could sound disparaging for ethnic groups. Thus, we recommend highlighting the species southern distribution confinement. See also earlier comments on the genus in B. bocagei.

1.14 Barbus steindachneri Almaça, 1967. Portuguese: Barbo de Steindachner. Standard name: Steindachner barbel. The species 
native range (mainly the Guadiana but also more locally the Tagus River basin) could well support the common name "Guadiana barbel" (Kottelat \& Freyhof, 2007). However, another Barbus (B. microcephalus) is also endemic to this basin leading to potential confusions. Therefore, we recommend the designation of "Steindachner barbel" already adopted in Portuguese literature in spite of being conscious that names intended to honour persons are without descriptive value. This is justified by the fact that the species has been considered in general by Spanish authors as a synonym of $B$. comizo (e.g., Doadrio, 2002) conversely to Portuguese (Almaça, 1967; Almaça \& Banarescu, 2003; Collares-Pereira et al., 2007) and other authors (Kottelat, 1997; Kottelat \& Freyhof, 2007) that do consider it as a distinct species from the Iberian long-snout barbel. See also earlier comments on the genus in B. bocagei.

1.15 Gobio lozanoi Doadrio \& Madeira, 2004. Spanish: Gobio. Portuguese: Góbio. Standard name: Pyrenean gudgeon. Recently, Iberian and southern-French gudgeon populations were described as a different species (Doadrio \& Madeira, 2004) based on genetic (Madeira et al., 2005) and morphometric evidences, no longer belonging to the morphologically variable G. gobio (Linnaeus, 1758), which has an almost pan-European distribution. Despite some controversy exists on the species natural distribution range (it is known to have invaded many Iberian catchments since the $19^{\text {th }}$ century both in Spain and in Portugal), recent consensus suggests that Adour (France) and Bidasoa (Spain) drainages —on each side of the Pyrenees - constitute its native area (Doadrio, 2001, 2002; Doadrio \& Madeira, 2004; Kottelat \& Persat, 2005), justifying the now proposed standard name instead of "Iberian gudgeon" (Kottelat \& Freyhof, 2007).

1.16 Iberochondrostoma almacai (Coelho, Mesquita \& Collares-Pereira, 2005). Portuguese: Boga do Sudoeste. Standard name: Southwestern arched-mouth nase. This recently described species is restricted to Mira, Arade and Bensafrim drainages in southwestern Portugal (Coelho et al., 2005). All Iberochondrostoma species have typically an arched-mouth and were earlier placed in Chondrostoma (but see comments on A. arcasii and $I$. olisiponensis), thus receiving names in combination with "nase". Although the Iberian endemicity of the genus (Robalo et al., 2007) could encourage proposing name combinations with the common name in Portuguese, "boga" is also a vernacular name for a marine fish species, the bogue Boops boops. Thus we recommend keeping the former and most well-known designation (Coelho et al., 2005) instead of the restricted one adopted by Kottelat \& Freyhof (2007) - "Mira pardelha". Moreover, the Portuguese word "pardelha" is also used as a vernacular name for Cobitis paludica in some regions of Portugal.

1.17 Iberochondrostoma lemmingii (Steindachner, 1866). Spanish: Pardilla. Portuguese: Boga-de-boca-arqueada. Standard name: Iberian arched-mouth nase. This endemic fish occurs in Spain and in Portugal (Tagus, Guadiana, Quarteira, Odiel, Douro and Guadalquivir drainages) being the species within this genus with the widest distribution range. Therefore, we recommend the use of a standard name that refers to its pan-central and southern Iberian geographic distribution and to the previously used common and informative "arched-mouth nase" designation. See also earlier comments on the genus in I. almacai.

1.18 Iberochondrostoma lusitanicum (CollaresPereira, 1980). Portuguese: Boga-Portuguesa. Standard name: Portuguese arched-mouth nase. The use of this common name seems adequate once the species is endemic to Portugal and has the widest geographic distribution when compared to the congeneric species restricted to Portuguese freshwaters ( $I$. almacai and I. olisiponensis). See also earlier comments on the genus in I. almacai.

1.19 Iberochondrostoma olisiponensis (Gante, Santos \& Alves, 2007). Portuguese: Bogade-boca-arqueada de Lisboa. Standard name: Lisbon arched-mouth nase. This species, 
highly confined, was recently described from the lower Tagus basin, in the vicinity of Lisbon (Gante et al., 2007). The species' description raised concerns on the proposed splitting of Chondrostoma by Robalo et al. (2007), since the new species did not fit exclusively into any of the proposed genera using morphological characters, and broke down combinations of traits diagnosing the newly erected genera. See also earlier comments in I. almacai for the reasoning of why the common name "Lisbon arched-mouth nase" suggested in the species' description article (Gante et al., 2007) is recommended.

1.20 Iberochondrostoma oretanum (Doadrio \& Carmona, 2003). Spanish: Pardilla oretana. Standard name: Oretanian arched-mouth nase. This recently described species is restricted to Robledillo and Fresneda rivers (tributaries of the Jándula River, Guadalquivir basin) (Doadrio \& Carmona, 2003), an area known as Oretania, justifying the combination with the informative "arched-mouth nase" designation as standard name. See also earlier comments on the genus in I. almacai.

1.21 Parachondrostoma arrigonis (Steindachner, 1866). Spanish: Loina. Standard name: Júcar nase. The species is endemic to the Júcar drainage in Spain (Elvira \& Almodóvar, 2008), and is currently included in the new genus Parachondrostoma (Robalo et al., 2007) (but see comments on A. arcasii and I. olisiponensis). The former taxonomic status (Chondrostoma) often led in the literature to English name combinations containing the name of their endemic drainage of origin followed by "nase" (e.g., Elvira \& Almodóvar, 2008), as we recommend here.

1.22 Parachondrostoma miegii (Steindachner, 1866). Spanish: Madrilla. Standard name: Ebro nase. The species is endemic to the Ebro River basin and adjacent smaller basins draining to the Bay of Biscay and Mediterranean Sea. Therefore, we recommend this geographic nomenclature instead of the Spanish name "Madrilla" (Kottelat \& Freyhof, 2007) which may well be confused with the verna- cular name of $P$. turiense — "Madrija". See earlier comments on the genus in P. arrigonis.

1.23 Parachondrostoma turiense (Elvira, 1987). Spanish: Madrija. Standard name: Turia nase. The species is endemic of the Turia and Mijares River basins (Elvira, 1987, 1997a). Therefore, we recommend this geographic nomenclature instead of the Spanish name "Madrija" (Kottelat \& Freyhof, 2007) which may well be confused with the vernacular name of $P$. miegii — "Madrilla". See earlier comments on the genus in P. arrigonis.

1.24 Phoxinus bigerri Kottelat, 2007. Spanish: Piscardo. Standard name: Pyrenean minnow. Until the recent systematic revision conducted by Kottelat (2007), all European Phoxinus were classified as $P$. phoxinus. Seven species are now recognized in European waters, including $P$. bigerri that is native to the Adour (France) and Ebro (Spain) River basins and some streams draining to the Bay of Biscay (Spain). Since Kottelat (2007) cautioned that the identification of the Iberian populations was tentative, we understand the suggested name "Adour minnow" could be acceptable. But, if future studies confirm Iberian minnow populations to belong to this species as described by Kottelat (2007), the name "Pyrenean minnow" is preferred.

1.25 Pseudochondrostoma duriense (Coelho, 1985). Spanish: Boga del Duero. Portuguese: Boga do Norte. Standard name: Northern straight-mouth nase. Species currently placed in the new Pseudochondrostoma genus (Robalo et al., 2007) (but see comments on A. arcasii and I. olisiponensis) have been named "straight-mouth nases" (e.g., Coelho, 1985) as we recommend here to differentiate from those placed in the genus $\mathrm{Pa}$ rachondrostoma. The species was formerly described from the Douro River basin, but its geographic distribution does range from the Vouga drainage in Portugal to the northern adjacent smaller basins of the Atlantic slope (Coelho, 1985; Elvira, 1997a; Aboim et al., 2009); therefore, the designation recommended here seems more adequate than 
the more confined "Douro nase" adopted by Kottelat \& Freyhof (2007).

1.26 Pseudochondrostoma polylepis (Steindachner, 1865). Spanish: Boga del Tajo. Portuguese: Boga comum. Standard name: Iberian straight-mouth nase. This straight-mouth nase has the widest distribution in Iberian freshwaters, ranging in Portugal from the central Mondego drainage to the southern Sado drainage including the Tagus drainage in both countries; therefore, the designation recommended here seems more adequate than the more restricted "Tagus nase" used by Kottelat \& Freyhof (2007). See also earlier comments on the genus in $P$. duriense.

1.27 Pseudochondrostoma willkommii (Steindachner, 1866). Spanish: Boga del Guadiana. Portuguese: Boga do Guadiana. Standard name: Southern straight-mouth nase. This species has been traditionally named as "Guadiana nase" (e.g., Kottelat \& Freyhof, 2007) once it occurs there but it is natural of a wider area including the Guadalquivir River basin along with other adjacent smaller rivers draining southern Iberian Peninsula. See earlier comments on the genus in P. duriense.

1.28 Squalius alburnoides (Steindachner, 1866) complex. Spanish: Calandino. Portuguese: Bordalo. Standard name: Calandino. This diploid-polyploid complex with a hybrid origin, was already assigned to several genera (Leuciscus, Rutilus and Tropidophoxinellus) (reviewed in Collares-Pereira et al., 1999), thus receiving common names in combination with "chub", "roach" and "minnow". Recently, Kottelat \& Freyhof (2007) transferred it from the commonly accepted last generic position in the genus Squalius to the Iberian genus Iberocypris, but this nomenclatural change has been challenged (Collares-Pereira \& Coelho, in press). The distribution range of the complex includes several Iberian drainages (namely Douro, Mondego, Tagus, Sado, Guadiana, Odiel, Guadalquivir and Quarteira) being wider in Spain. Therefore we recommend the standard adoption of the Spanish designation.
1.29 Squalius aradensis (Coelho, Bogutskaya, Rodrigues \& Collares-Pereira, 1998). Portuguese: Escalo do Arade. Standard name: Arade chub. Iberian Squalius species were until recently (Sanjur et al., 2003) placed in the genus Leuciscus, and therefore traditionally named as "chubs" in the literature. Most Squalius are endemic at drainage level, justifying name combinations of their drainage (area) of origin followed by "chub". This species is confined to Portugal and inhabits the Arade and some other small drainages in the south (Coelho et al., 1998; Mesquita \& Coelho, 2002; Mesquita et al., 2005).

1.30 Squalius carolitertii (Doadrio, 1988). Spanish: Bordallo. Portuguese: Escalo do Norte. Standard name: Northern Iberian chub. Species distribution ranges from the most northern smaller drainages of the Atlantic slope to the Mondego drainage in Portugal (Doadrio, 1987; Coelho et al., 1998; Carmona \& Doadrio, 2000). Thus, we recommend this designation instead of the Spanish vernacular name "Bordallo" adopted by Kottelat \& Freyhof (2007). See earlier comments on the genus in $S$. aradensis.

1.31 Squalius castellanus Doadrio, Perea \& Alonso, 2007. Spanish: Bordallo del Gallo. Standard name: Gallo chub. This species was recently described from the Gallo River and its tributaries in the upper Tagus drainage in Spain (Doadrio et al., 2007b). See earlier comment on the genus in S. aradensis.

1.32 Squalius laietanus Doadrio, Kottelat \& Sostoa, 2007. Spanish: Bagre. Standard name: Ebro chub. This recently described species is endemic of the Ebro River basin and other neighbouring smaller basins of the Mediterranean slope (Doadrio et al., 2007a). We discourage from using "Catalan chub" (Kottelat \& Freyhof, 2007) since Catalonia is only one of the nine autonomous regions sharing the Ebro River basin. See earlier comments on the genus in $S$. aradensis.

1.33 Squalius malacitanus Doadrio \& Carmona, 2006. Spanish: Cacho malagueño. Standard name: Málaga chub. The species known 
distribution range is restricted to three small rivers in the province of Málaga (Doadrio \& Carmona, 2006), justifying the translation of the scientific name (Kottelat \& Freyhof, 2007). See earlier comments on the genus in $S$. aradensis.

1.34 Squalius palaciosi (Doadrio, 1980) complex. Spanish: Bogardilla. Standard name: Bogardilla. After the species description in the new genus Iberocypris Doadrio, 1980, diploid, triploid and tetraploid specimens were found to exist and a direct link of palaciosi complex with Squalius pyrenaicus was later confirmed (Zardoya \& Doadrio, 1998; Zardoya \& Doadrio, 1999; Sanjur et al., 2003; Doadrio \& Carmona, 2006). Recently, Kottelat \& Freyhof (2007) returned palaciosi to the first generic position in the genus Iberocypris but this change has not yet been accurately supported (Collares-Pereira \& Coelho, in press). This highly confined endemism occurs in the middle Guadalquivir basin —right side tributaries Rumblar, Jándula and Robledo (Elvira, 1997b) - thus it should be recognised by its local Spanish name.

1.35 Squalius pyrenaicus (Günther, 1868). Spanish: Cacho. Portuguese: Escalo do Sul. Standard name: Southern Iberian chub. This species has the widest distribution range in Iberia compared to other members of the genus, practically all the southern half of the Peninsula, justifying the proposed designation, instead of the common name in Spanish "cacho" used by Kottelat \& Freyhof (2007). See earlier comments on the genus in $S$. aradensis.

1.36 Squalius torgalensis (Coelho, Bogutskaya, Rodrigues \& Collares-Pereira, 1998). Portuguese: Escalo do Mira. Standard name: Mira chub. The species is endemic of the Mira River basin, southwestern Portugal (Coelho et al., 1998). See earlier comments on the genus in $S$. aradensis.

1.37 Squalius valentinus Doadrio \& Carmona, 2006. Spanish: Cacho valenciano. Standard name: Eastern Iberian chub. The species is endemic to the rivers draining to the Medite- rranean Sea between the Mijares and Vinalopó basins (Doadrio \& Carmona, 2006) in the eastern coast of Spain. This designation is recommended over "Valencia chub" (Kottelat \& Freyhof, 2007) because Valencia is only one of the provinces within the distribution area of the species. See earlier comments on the genus in $S$. aradensis.

\section{Family Cobitidae}

2.1 Cobitis calderoni Băcescu, 1962. Spanish: Lamprehuela. Portuguese: Verdemã do Norte. Standard name: Northern Iberian spinedloach. Species of Cobitis known from most of Europe, temperate Asia and Northern Africa are commonly named in the literature as "spined loaches" and therefore we recommend the adoption of this commnon name instead of the Spanish designation as done by Kottelat \& Freyhof (2007). This species inhabits the northern half of the Peninsula, mainly in Ebro and Douro River basins but also in a few headwaters of rivers draining to the Tagus River (Perdices \& Doadrio, 1997a).

2.2 Cobitis paludica (de Buen, 1930). Spanish: Colmilleja. Portuguese: Verdemã comum. Standard name: Southern Iberian spinedloach. This species inhabits most rivers in central and southern Iberia (Perdices \& Doadrio, 1997b), justifying our recommendation for this common name. See earlier comments on the genus in $C$. calderoni.

2.3 Cobitis vettonica Doadrio \& Perdices, 1997. Spanish: Colmilleja del Alagón. Standard name: Vettonian spined-loach. The species is restricted to the Alagón River system (Tagus basin) and its latin name was derived from the name of the local inhabitants in old times (Vettonians) (Doadrio \& Perdices, 1997), justifying our recommendation for this designation. See earlier comments on the genus in $C$. calderoni.

\section{Family Nemacheilidae (Balitoridae)}

3.1 Barbatula quignardi (Băcescu-Mester, 1967). Spanish: Lobo de Río. Standard name: Pyrenean stone loach. Stone loach populations 
from both sides of the Pyrenees, namely from the Ebro River basin, some rivers draining to the Bay of Biscay and south-western (Aquitaine) and south-eastern (Languedoc) France, are now considered as a distinct species (Kottelat \& Freyhof, 2007). The proposed designation making reference to the circum-Pyrenean distribution of this species should be standardized instead of others more inaccurate (e.g., "Languedoc stone loach", Kottelat \& Freyhof, 2007).

\section{Family Valenciidae}

4.1 Valencia hispanica (Valenciennes, 1846). Spanish: Samaruc. Standard name: Samaruc. This family with a single genus and only two species was formerly included in Cyprinodontidae and thus it has been traditionally named with the combined designation "toothcarp" (Oliva-Paterna et al., 2009). Based on the species distribution range (Spain, along the Mediterranean coast), we recommend the use of the well-known Spanish designation (e.g., Kottelat \& Freyhof, 2007) to avoid misinterpretations.

\section{Family Cyprinodontidae}

5.1 Aphanius baeticus Doadrio, Carmona \& Fernández-Delgado, 2002. Spanish: Salinete. Standard name: Baetican toothcarp. This recently described species occurs in the lower reaches of the River Guadalquivir and streams located on the southern Atlantic slope, an area known as "Baetica" by romans (Doadrio et al., 2002; Oliva-Paterna et al., 2006a). Thus we recommend the standardization of the designation of this well-known area instead of other more restricted common names (e.g., "Guadalquivir toothcarp", Kottelat \& Freyhof, 2007).

5.2 Aphanius iberus (Valenciennes, 1846). Spanish: Fartet. Standard name: Iberian toothcarp. The species occurs only along the Mediterranean coast of Spain, and even the name might suggest a wider distribution, we found appropriate to keep this well-known standard designation traditionally adopted in literature (Oliva-Paterna et al., 2006b) that derives from the scientific name.

\section{Family Cottidae}

6.1 Cottus aturi Freyhof, Kottelat \& Nolte, 2005. Spanish: Burtaina. Standard name: Adour sculpin. After the recent taxonomic revision of European species of Cottus, as much as 15 species are recognized (Freyhof et al., 2005). We found this standard designation as adopted by Kottelat \& Freyhof (2007) well appropriate for the sculpin populations from the Adour River basin (France, Spain) and the smaller Nivelle (France, Spain) and Bidasoa (Spain) drainages, now recognized as a distinct species.

6.2 Cottus hispaniolensis Băcescu \& BăcescuMester, 1964. Spanish: Cavilat. Standard name: Pyrenean sculpin. We found this designation well appropriate for the sculpin populations from Pyrenean Garonne drainage (France, Spain) (Kottelat \& Freyhof, 2007), now recognized as a distinct species. See earlier comments on the genus in $C$. aturi.

\section{REFERENCES}

ABOIM, M. A., C. CUNHA \& M. M. COELHO. 2009. Redistribution of the geographical ranges of the Iberian cyprinid genus Pseudochondrostoma based on a phylogenetic analysis: implications for the historical rearrangements of the north-western Iberian drainages. J. Fish Biol., 74: 1337-1346.

ALMAÇA, C. 1967. Estudo das populações portuguesas do gén. Barbus Cuvier, 1817 (Pisces, Cyprinidae). Rev. Fac. Ciênc., Univ. Lisboa, Ser. C: Ciênc. Nat., 14: 151-400.

ALMAÇA, C. \& P. M. BĂNĂRESCU. 2003. Barbus comizo Steindachner, 1865. In: The Freshwater Fishes of Europe. Bănărescu, P. M. \& N. G. Bogutskaya (eds.): 173-180. Aula-Verlag, Wiesbaden, Germany.

CARMONA, J. A. \& I. DOADRIO. 2000. Threatened fishes of the World: Leuciscus carolitertii Doadrio, 1988 (Cyprinidae). Environ. Biol. Fish., 57: 96.

COELHO, M. M. 1985. The straight mouth Portuguese Chondrostoma Agassiz, 1835. II-Taxonomic 
position and geographic distribution of Ch. polylepis Steindachner, 1865 and Ch. willkommii Steindachner, 1866 with the description of a new subspecies -Ch. polylepis duriensis. Arquivos do $\mathrm{Mu}$ seu Bocage Serie A, 3: 13-38.

COELHO, M. M., N. G. BOGUTSKAYA, J. A. RODRIGUES \& M. J. COLLARES-PEREIRA. 1998. Leuciscus torgalensis, and L. aradensis, two new cyprinids for Portuguese fresh waters. J. Fish Biol., 52: 937-950.

COELHO, M. M., N. MESQUITA \& M. J. COLLARES-PEREIRA. 2005. Chondrostoma almacai, a new cyprinid species from the southwest of Portugal, Iberian Peninsula. Folia Zool., 54: 201-212.

COLLARES-PEREIRA, M. J. \& C. ALMAÇA. 1979. Pseudophoxinus hispanicus (Steind., 1866), Cyprinidae nouveau pour le Portugal. Bull. Mus. Natn. Hist. Nat. Paris, 4e Ser. 1, Sect. A(1): 285-287.

COLLARES-PEREIRA, M. J., M. J. ALVES \& M. M. COELHO. 1999. Reassessment of the generic position of the Iberian cyprinid alburnoides complex: its return to the genus Leuciscus. J. Fish Biol., 54: 465-468.

COLLARES-PEREIRA, M. J. \& M. M. COELHO. (in press). Reconfirming the hybrid origin and the generic status of the Iberian cyprinid complex Squalius alburnoides. J. Fish Biol.

COLLARES-PEREIRA, M. J. \& I. G. COWX. 2001. Threatened fishes of the World: Anaecypris hispanica (Steindachner, 1866) (Cyprinidae). Environ. Biol. Fish., 60: 410.

COLLARES-PEREIRA, M. J., A. F. FILIPE \& L. MOREIRA DA COSTA. 2007. Os Peixes do Rio Guadiana: Que futuro? Guia dos Peixes do Guadiana Português. Alpiarça, Portugal: Edições Cosmos. 294 pp.

DOADRIO, I. 1987. Leuciscus carolitertii n. sp. from the Iberian Peninsula (Ostariophysi, Cyprinidae). Senckenbergiana Biologica, 68: 301-309.

DOADRIO, I. (ed.). 2001. Atlas y libro rojo de los peces continentales de España. Madrid: Dirección General de Conservación de la Naturaleza, Museo Nacional de Ciencias Naturales. 364 pp.

DOADRIO, I. (ed.). 2002. Atlas y libro rojo de los peces continentales de España. Madrid: Dirección General de Conservación de la Naturaleza, Museo Nacional de Ciencias Naturales. 374 pp.

DOADRIO, I. \& J. A. CARMONA. 2003. A new species of the genus Chondrostoma Agassiz, 1832 (Actinopterygii, Cyprinidae) from the Iberian Peninsula. Graellsia, 59: 29-36.
DOADRIO, I. \& J. A. CARMONA. 2006. Phylogenetic overview of the genus Squalius (Actinopterygii, Cyprinidae) in the Iberian Peninsula, with description of two new species. Cybium, 30: 199-214.

DOADRIO, I., J. A. CARMONA \& C. FERNÁNDEZ-DELGADO. 2002. Morphometric study of the Iberian Aphanius (Actinopterygii, Cyprinodontiformes), with description of a new species. Folia Zool., 51: 67-79.

DOADRIO, I. \& B. ELVIRA. 2007. A new species of the genus Achondrostoma Robalo, Almada, Levy \& Doadrio, 2007 (Actinopterygii, Cyprinidae) from western Spain. Graellsia, 63: 295-304.

DOADRIO, I., M. KOTTELAT \& A. DE SOSTOA. 2007a. Squalius laietanus, a new species of cyprinid fish from north-eastern Spain and southern France (Teleostei: Cyprinidae). Ichthyol. Explor. Freshwaters, 18: 247-256.

DOADRIO, I. \& M. J. MADEIRA. 2004. A new species of the genus Gobio Cuvier, 1816 (Actynopterigii, Cyprinidae) from the Iberian Peninsula and Southwestern France. Graellsia, 60: 107-116.

DOADRIO, I. \& A. PERDICES. 1997. Taxonomic study of the Iberian Cobitis (Osteichthyes, Cobitidae), with description of a new species. Zool. J. Linn. Soc., 119: 51-67.

DOADRIO, I. \& A. PERDICES. 1998. Threatened fishes of the World: Barbus comiza Steindachner, 1865 (Cyprinidae). Environ. Biol. Fish., 51: 52-52.

DOADRIO, I., S. PEREA \& F. ALONSO. 2007b. A new species of the genus Squalius Bonaparte, 1837 (Actinopterygii, Cyprinidae) from the Tagus River Basin (Central Spain). Graellsia, 63: 89-100.

ELVIRA, B. 1987. Taxonomic revision of he genus Chondrostoma Agassiz, 1835 (Pisces, Cyprinidae). Cybium, 11: 111-140.

ELVIRA, B. 1997a. Taxonomy of the genus Chondrostoma (Osteichthyes, Cyprinidae): An updated review. Folia Zool., 46: 1-14.

ELVIRA, B. 1997b. Threatened fishes of the World: Iberocypris palaciosi Doadrio, 1980 (Cyprinidae). Environ. Biol. Fish., 50: 104.

ELVIRA, B. \& A. ALMODÓVAR. 2008. Threatened fishes of the World: Chondrostoma arrigonis (Steindachner, 1866) (Cyprinidae). Environ. Biol. Fish., 81: 27-28.

FREYHOF, J., M. KOTTELAT \& A. NOLTE. 2005. Taxonomic diversity of European Cottus with description of eight new species (Teleostei: Cottidae). Ichthyol. Explor. Freshwaters, 16: 107-172. 
FROESE, R. \& D. PAULY. 2008. FishBase. World Wide Web electronic publication. www.fishbase. org. Accessed on 05 July 2008.

GANTE, H. F., C. D. SANTOS \& M. J. ALVES. 2007. A new species of Chondrostoma Agassiz, 1832 (Cypriniformes: Cyprinidae) with sexual dimorphism from the lower Rio Tejo Basin, Portugal. Zootaxa, 1616: 25-35.

IUCN. 2008. The IUCN Red List of Threatened Species. www.iucnredlist.org. Downloaded on 05 July 2008.

KOTTELAT, M. 1997. European freshwater fishes. An heuristic checklist of the freshwater fishes of Europe (exclusive of former USSR), with an introduction for non-systematists and comments on nomenclature and conservation. Biologia, Bratislava, Section Zoology, 52: 1-271.

KOTTELAT, M. 2007. Three new species of Phoxinus from Greece and southern France (Teleostei: Cyprinidae). Ichthyol. Explor. Freshwaters, 18: 145-162.

KOTTELAT, M. \& J. FREYHOF. 2007. Handbook of European Freshwater Fishes. Kottelat, Cornol, Switzerland and Freyhof, Berlin, Germany. $646 \mathrm{pp}$.

KOTTELAT, M. \& H. PERSAT. 2005. The genus Gobio in France, with redescription of G. gobio and description of two new species (Teleostei: $\mathrm{Cy}$ prinidae). Cybium, 29: 211-234.

MADEIRA, M. J., B. J. GÓMEZ-MOLINER \& I. DOADRIO. 2005. Genetic characterization of Gobio gobio populations of the Iberian Peninsula based on cytochrome $b$ sequences. Folia Zool., 54 (Suppl. 1): 5-12.

MESQUITA, N. \& M. M. COELHO. 2002. The ichthyofauna of the small Mediterranean-type drainages of Portugal: its importance for conservation. In: Conservation of Freshwater Fishes: Options for the Future. Collares-Pereira, M.J., I.G. Cowx \& M. M. Coelho (eds.): 65-71. Fishing News Books, Blackwell Science, Oxford.

MESQUITA, N., B. HANFLING, G. R. CARVALHO \& M. M. COELHO. 2005. Phylogeography of the cyprinid Squalius aradensis and implications for conservation of the endemic freshwater fauna of southern Portugal. Molecular Ecology, 14: 1939-1954.

MIRANDA, R., P. M. LEUNDA, C. ESCALA \& J. OSCOZ. 2005. Threatened fishes of the World: Barbus haasi (Mertens 1925) (Cyprinidae). Environ. Biol. Fish., 72: 282.
NELSON, J. S., E. J. CROSSMAN, H. ESPINOSAPÉREZ, L. T. FINDLEY, C. R. GILBERT, R. N. LEA \& J. D. WILLIAMS. 2004. Common and Scientific Names of Fishes from the United States, Canada and Mexico Sixth Edition. Beteshda, Maryland: American Fisheries Society. 386 pp.

OLIVA-PATERNA, F., I. DOADRIO \& C. FERNÁNDEZ-DELGADO. 2006a. Threatened fishes of the World: Aphanius baeticus (Doadrio, Carmona \& Fernández Delgado, 2002) (Cyprinodontidae). Environ. Biol. Fish., 75: 415-417.

OLIVA-PATERNA, F. J., M. TORRALVA \& C. FERNÁNDEZ-DELGADO. 2006b. Threatened fishes of the World: Aphanius iberus (Cuvier \& Valenciennes, 1846) (Cyprinodontidae). Environ. Biol. Fish., 75: 307-309.

OLIVA-PATERNA, F. J., N. CAIOLA \& M. TORRALVA. 2009. Threatened fishes of the worl: $\mathrm{Va}$ lencia hispanica (Valenciennes, 1846) (Valenciidae). Environ. Biol. Fish., 85:275-276.

PERDICES, A. \& I. DOADRIO. 1997a. Threatened fishes of the World: Cobitis calderoni Băcescu, 1961 (Cobitidae). Environ. Biol. Fish., 50: 148.

PERDICES, A. \& I. DOADRIO. 1997b. Threatened fishes of the World: Cobitis paludica (De Buen, 1930) (Cobitidae). Environ. Biol. Fish., 49: 360.

RIBEIRO, F., R. BELDADE, M. DIX \& J. BOCHECHAS. 2007. Carta Piscícola Nacional. www. cartapiscicola.org. Accessed on 05 July 2008. Direcção Geral dos Recursos Florestais \& Fluviatilis, Lda.

ROBALO, J., C. SOUSA-SANTOS, I. DOADRIO \& V. ALMADA. 2008. Threatened fishes of the world: Achondrostoma occidentale Robalo, Almada, Sousa-Santos, Moreira \& Doadrio 2005 (Cyprinidae). Environ. Biol. Fish., 83: 347.

ROBALO, J. I., V. C. ALMADA, A. LEVY \& I. DOADRIO. 2007. Re-examination and phylogeny of the genus Chondrostoma based on mitochondrial and nuclear data and the definition of 5 new genera. Mol. Phylogenet. Evol., 42: 362-372.

ROBALO, J. I., V. C. ALMADA, C. SOUSA-SANTOS, M. I. MOREIRA \& I. DOADRIO. 2005a. New species of the genus Chondrostoma Agassiz, 1832 (Actynopterigii, Cyprinidae) from western Portugal. Graellsia, 61: 19-29.

ROBALO, J. I., I. DOADRIO, V. C. ALMADA \& M. KOTTELAT. 2005b. Chondrostoma oligolepis, new replacement name for Leuciscus macrolepidotus Steindachner, 1866 (Teleostei: Cyprinidae). Ichthyol. Explor. Freshwaters, 16: 47-48. 
ROGADO, L., P. ALEXADRINO, P. R. ALMEIDA, M. J. ALVES, J. BOCHECHAS, R. CORTES, I. DOMINGOS, A. F. FILIPE, J. MADEIRA \& M. F. MAGALHÃES. 2005. Peixes. In: Livro Vermelho dos Vertebrados de Portugal. Cabral, M. J., J. Almeida, P. R. Almeida, T. Dellinger, N. Ferrand-Almeida, M. E. Oliveira, J. M. Palmeirim, A. I. Queiros, L. Rogado \& M. Santos-Reis (eds.): 63-114. Instituto da Conservação da Natureza, Lisboa, Portugal.

SANJUR, O. I., J. A. CARMONA \& I. DOADRIO. 2003. Evolutionary and biogeographical patterns within Iberian populations of the genus Squalius inferred from molecular data. Mol. Phylogenet. Evol., 29: 20-30.

WHEELER, A. C. 1992. A List of the Common and
Scientific Names of Fishes of the British Isles. $J$. Fish Biol., 41: 1-26.

WHEELER, A. C., N. R. MERRETT \& D. T. G. QUIGLEY. 2004. Additional records and notes for Wheeler's (1992) List of the Common and Scientific Names of Fishes of the British Isles. J. Fish Biol., 65: 1-40.

ZARDOYA, R. \& I. DOADRIO. 1998. Phylogenetic relationships of Iberian cyprinids: Systematic and biogeographical implications. Proc. R. Soc. Lond. $B, 265$ : 1365-1372.

ZARDOYA, R. \& I. DOADRIO. 1999. Molecular evidence on the evolutionary and biogeographical patterns of European cyprinids. J. Mol. Evol., 49: 227-237. 